\title{
Daya Hasil dan Kualitas Jagung Manis Genotipe SD3 dengan Empat Varietas Pembanding di Kabupaten Bandung
}

\section{Sweet Corn Quality and Yield of Genotype SD3 with Four Comparison Varieties in Bandung}

\author{
Muhammad Hilal dan Memen Surahman*
}

Departemen Agronomi dan Hortikultura, Fakultas Pertanian, Institut Pertanian Bogor (Bogor Agricultural University), Jl. Meranti, Kampus IPB Darmaga, Bogor 16680, Indonesia Telp.\&Faks.62-251-8629353 e-mail agronipb@indo.net.id

*Penulis untuk korespondensi: memensurahman@yahoo.com

Disetujui : 14 November 2015 / Published online 12 Desember 2015

\begin{abstract}
The productivity of sweet corn is low caused by not using superior seed. The hybrid sweet corn seed price is expensive. The cheap of non-hybrid sweet corn seed is not available in the market. SD3 (openpollinated variety) assembled to share a cheaper seed for farmers. The objective of this research was to evaluate yield, quality and performance of sweet corn genotype SD3 compared to four varieties (Super Sweet, Bonanza, Sweet Boy, and SG 75). The experiment was conducted from 30 June to 1 Oktober 2012 using a Randomized Complete Block Design with one factor and four replications at Banjaran, Cimaung sub district, Bandung regency. Based on research result, genotype SD3 is higher than Super Sweet (openpollinated variety) for kernel row number and total soluble solid level. Meanwhile, when compared to Bonanza and Sweet Boy (hybrid variety), genotype SD3 can not compete. Bonanza is higher than SD3 for ear diameter, ear weight with cornhusk, ear weight without cornhusk and productivity. Sweet Boy is higher than SD3 for ear length and ear diameter. Genotype SD3 is the same as SG 75 (hybrid variety) in all variables except for vegetative variable, those are plant height and main ear height.
\end{abstract}

Keywords : sweet corn, SD3, quality, yield

\begin{abstract}
ABSTRAK
Produktivitas jagung manis rendah karena penggunaan benih tidak unggul oleh petani. Benih jagung manis hibrida unggul harganya mahal. Benih jagung manis non hibrida murah belum tersedia. Varietas SD3 (varietas bersari bebas) dirakit sebagai benih yang lebih murah bagi petani. Tujuan penelitian ini adalah menguji daya hasil, kualitas, dan penampilan jagung manis genotipe SD3 dengan empat varietas pembanding (Super Sweet, Bonanza, Sweet Boy, dan SG 75). Penelitian dilaksanakan pada 30 Juni sampai dengan 1 Oktober 2012 menggunakan Rancangan Kelompok Lengkap Teracak dengan satu faktor dan empat ulangan di Desa Banjaran, Kecamatan Cimaung, Kabupaten Bandung. Berdasarkan penelitian, genotipe SD3 lebih unggul dibandingkan dengan Super Sweet (varietas bersari bebas) pada jumlah baris biji dan kadar padatan terlarut total, sedangkan jika dibandingkan dengan Bonanza dan Sweet Boy (varietas hirbida), genotipe SD3 masih belum bisa bersaing. Bonanza lebih unggul dibandingkan SD3 pada diameter tongkol, bobot tongkol berkelobot, bobot tongkol tanpa kelobot dan produktivitas. Sweet Boy lebih unggul dibandingkan SD3 pada panjang dan diameter tongkol. Genotipe SD3 dibandingkan dengan SG 75 (varietas hibrida) tidak ada perbedaan pada seluruh peubah kecuali pada peubah vegetatif yaitu tinggi tanaman dan tinggi tongkol utama.
\end{abstract}

Kata kunci : daya hasil, jagung manis, kualitas, SD3 


\section{PENDAHULUAN}

Jagung manis (Zea mays saccharata Sturt.) merupakan komoditas pertanian yang sangat digemari karena rasanya yang manis, mudah diolah, mengandung sedikit protein dan lemak. Biji jagung manis mengandung banyak sukrosa, sedikit glukosa, fruktosa, maltosa dan pati (Rubatzky dan Yamaguchi, 1995). Kandungan protein jagung manis $10.3 \mathrm{~g} / 100 \mathrm{~g}$ (Setyani et al., 2009). Tanaman jagung manis umumnya dipanen 18-24 hari setelah penyerbukan (Rubatzky dan Yamaguchi, 1995) atau sekitar 70 hari setelah tanam. Umur yang relatif pendek ini memungkinkan frekuensi penanaman yang lebih intensif dibandingkan dengan menanam jagung biasa. Sisa brangkasan dapat dimanfaatkan sebagai pakan ternak karena masih hijau saat dipanen. Tongkol jagung sekunder dapat dijadikan sebagai jagung semi.

Permintaan pasar nasional dan internasional terhadap jagung manis cenderung meningkat. Oleh karena itu luas areal tanam jagung manis juga terus meningkat. Untuk memenuhi kebutuhan benih jagung manis dalam negeri, Indonesia masih mengimpor benih dari luar negeri dengan volume yang melebihi ekspor. Volume impor benih jagung manis pada tahun 2010 adalah 282.3 ton, sedangkan volume ekspor benih di tahun yang sama 31.6 ton (Deptan, 2012). Akibat impor yang besar, jumlah dana yang digunakan untuk membayar impor benih lebih besar dibandingkan dana yang diperoleh dari ekspor benih jagung manis. Nilai Impor benih jagung manis pada tahun 2010 adalah USD 2540 808 dan nilai ekspor benih di tahun yang sama adalah USD 379200 (Deptan, 2012). Varietas yang dirilis oleh perusahaan benih swasta adalah varietas jagung manis hibrida yang relatif mahal. Benih jagung manis non hibrida yang harganya murah masih belum tersedia secara memadai dan belum dapat bersaing dalam hal produktivitas dengan benih hibrida. Fred Rumawas, peneliti dari Institut Pertanian Bogor (IPB), merakit variaetas SD3 (Seleksi Dramaga 3) yang merupakan varietas bersari bebas untuk menyediakan benih yang lebih murah bagi petani. Penelitian ini ingin menguji apakah genotipe SD3 dapat bersaing dengan varietas lainnya dalam hal daya hasil, kualitas, dan penampilan di ketinggian (altitude) sedang (Banjaran, Bandung).

Tujuan penelitian ini adalah untuk melakukan uji daya hasil, kualitas, dan penampilan jagung manis (Zea mays saccharata Sturt.) genotipe SD3 dengan empat varietas komersial lainnya di Kabupaten Bandung.

\section{BAHAN DAN METODE}

Penelitian dilakukan di Desa Cimaung, Kecamatan Banjaran, Kabupaten Bandung pada 30 Juni sampai dengan 1 Oktober 2012. Kabupaten Bandung terletak pada koordinat 107.5 BT dan 7.0 LS dengan ketinggian tempat $809 \mathrm{~m}$ dpl, beriklim tropis yang dipengaruhi oleh iklim munson dengan curah hujan rata-rata antara 1500 $\mathrm{mm}$ sampai dengan $4000 \mathrm{~mm}$ per tahun. Suhu udara $12-24{ }^{\circ} \mathrm{C}$ dengan kelembaban udara $78 \%$ pada musim hujan (Pemkab Bandung 2011).

Bahan tanaman yang akan digunakan dalam penelitian ini adalah satu genotipe jagung manis, yaitu: SD 3. Jagung manis varietas Super Sweet (varietas bersari bebas), Bonanza, Sweet Boy, dan Sugar 75 (varietas hibrida) digunakan sebagai varietas pembanding. Pupuk yang digunakan dalam penelitian ini yaitu pupuk Urea $300 \mathrm{~kg} / \mathrm{ha}$, pupuk SP $36200 \mathrm{~kg} / \mathrm{ha}$, pupuk $\mathrm{KCl}$ $200 \mathrm{~kg} / \mathrm{ha}$, dan pupuk kandang 15 ton/ha. Kapur diberikan dengan dosis 1.5 ton/ha. Bahan lain yang digunakan dalam penelitian ini adalah pestisida berbahan aktif Carbofuran dan Metalaxyl 35\% dengan dosis 2 gram $/ \mathrm{kg}$ benih dan 2 gram/l air sebagai fungisida.

Peralatan yang digunakan dalam penelitian ini adalah peralatan budi daya tanaman standar, timbangan, jangka sorong, meteran, dan refraktometer untuk mengukur kadar Padatan Total Terlarut (PTT) pada biji jagung manis.

Penelitian ini menggunakan rancangan kelompok lengkap teracak (RKLT) faktor tunggal yaitu varietas jagung manis dengan empat ulangan. Faktor perlakuan (varietas) terdiri atas 5 taraf yaitu 1 genotipe jagung manis (SD3) dan 4 varietas pembanding (Super Sweet, Sweet Boy, Bonanza, SG 75). Setiap satuan percobaan terdiri atas petak berukuran $4 \mathrm{~m} \times 5 \mathrm{~m}$.

Uji $F$ digunakan untuk menganalisis pengaruh perlakuan. Jika perlakuan berpengaruh nyata, dilakukan perbandingan nilai tengah SD3 dengan varietas pembanding dengan uji Dunnett pada taraf 5\% dengan software Minitab 16.

Lahan diolah satu minggu sebelum penanaman dengan diberikan kapur dan pupuk kandang kemudian diratakan dan dibagi menjadi empat blok. Masing-masing blok terdiri atas lima petak. Jarak antar blok $1.5 \mathrm{~m}$. Dalam satu petak terdapat lima baris tanaman dengan jarak tanam $76 \mathrm{~cm}$ antar baris dan $25 \mathrm{~cm}$ dalam baris. Benih yang ditanam yaitu 2 benih/lubang. Pupuk dasar diberikan satu minggu setelah tanam dengan dosis setengah dosis pupuk Urea serta seluruh dosis pupuk $\mathrm{KCl}$ dan SP-36. Pemberian pupuk dilakukan dengan sistem tugal berjarak $5-7 \mathrm{~cm}$ dari lubang tanaman. Pengairan diberikan 
sebanyak dua kali setiap minggu selama penelitian dengan cara menggenangi parit-parit antar petakpetak percobaan. Tanaman jagung manis dibumbun pada saat 3 MST. Pemupukan kedua yaitu pemberian Urea dilakukan saat tanaman berumur 4 MST. Pengendalian hama yaitu dengan pemberian pestisida berbahan aktif Carbofuran \pm 5 butir per lubang tanam saat penanaman. Pengamatan tanaman contoh dilakukan dengan mengambil 10 lubang contoh dalam setiap satuan percobaan. Pengamatan ditujukan pada peubahpeubah yang mencerminkan keragaan tanaman di lapangan, pertumbuhan vegetatif dan generatif, kuantitas, dan kualitas hasil.

\section{HASIL DAN PEMBAHASAN}

\section{Karakter Agronomi}

Daya berkecambah genotipe SD3 $(89.5 \%)$ tidak berbeda nyata dengan empat varietas komersial yang digunakan sebagai pembanding. Genotipe SD3 mempunyai daya berkecambah $89.5 \%$ sedangkan empat varietas pembanding memiliki kisaran daya berkecambah $85.8 \%$ sampai $92.6 \%$. Daya berkecambah masingmasing varietas sebagai berikut, Super Sweet (92.6\%), Bonanza (91.3\%), Sweet Boy (85.8\%), dan SG 75 (91.8\%). Daya berkecambah SD3 relatif lebih rendah dibandingkan dengan semua varietas pembanding kecuali Sweet Boy. Umur panen per petak tanaman tidak berbeda nyata karena semua tanaman dipanen serempak pada 90 hari setelah tanam (HST).

Tabel 2. Nilai tengah daya berkecambah dan umur panen

\begin{tabular}{lcc}
\hline \multicolumn{1}{c}{ Varietas } & $\begin{array}{c}\text { Daya berkecambah } \\
(\%)\end{array}$ & Umur panen (hari) \\
\hline SD3 & 89.5 & 90 \\
Super Sweet & 92.6 & 90 \\
Bonanza & 91.3 & 90 \\
Sweet Boy & 85.8 & 90 \\
SG 75 & 91.8 & 90 \\
\hline
\end{tabular}

Tinggi tanaman dan tinggi tongkol utama genotipe SD3 berbeda nyata dengan varietas pembanding kecuali Bonanza, sedangkan diameter batang tidak berbeda nyata dengan varietas pembanding. Genotipe SD3 memiliki ukuran diameter batang $19.3 \mathrm{~cm}$, sedangkan empat varietas komersial yang dijadikan pembanding memiliki kisaran diameter batang antara 19.3 sampai $22.8 \mathrm{~cm}$. Tinggi tanaman genotipe SD3 $(253.0 \mathrm{~cm})$ berbeda nyata dengan Super Sweet $(274.4 \mathrm{~cm})$, Sweet Boy $(225.6 \mathrm{~cm})$, dan SG $75(222.2 \mathrm{~cm})$, sedangkan dengan
Bonanza $(258.9 \mathrm{~cm})$ tidak berbeda nyata. Genotipe SD3 memiliki tinggi tanaman lebih tinggi dibandingkan dengan Sweet Boy dan SG 75 tetapi lebih pendek dari Super Sweet. Tinggi tanaman jagung manis penelitian lebih tinggi dibandingkan dengan deskripsi varietas kemungkinan karena pengaruh ketinggian tempat (altitude), cuaca yang relatif basah dan sering berawan. Hal ini sesuai dengan penilitian Kumalasari et al. (2005) yang memperoleh hasil tinggi tanaman jagung manis yang ditanam pada musim hujan lebih tinggi daripada yang ditanam musim kemarau.

Tinggi tongkol utama genotipe SD3 $(147.6 \mathrm{~cm})$ berbeda nyata dengan Super Sweet $(171.0 \mathrm{~cm})$, Sweet Boy $(93.9 \mathrm{~cm})$ dan SG 75 $(124.2 \mathrm{~cm})$. Tinggi tongkol utama SD3 lebih tinggi dari varietas hibrida pembanding (Sweet Boy dan SG 75) tetapi lebih rendah dari varietas bersari bebas (Super Sweet). Tinggi tongkol tidak berhubungan dengan tinggi tanaman (Sufiani 2002). Tinggi tongkol lebih dipengaruhi oleh faktor genetik dibandingkan lingkungan (Admaja 2006).

Tabel 3. Nilai tengah tinggi tanaman, tinggi tongkol utama, dan diameter batang genotipe SD3 dengan empat varietas komersial sebagai pembanding

\begin{tabular}{lccc}
\hline Varietas & $\begin{array}{c}\text { Tinggi } \\
\text { tanaman } \\
(\mathrm{cm})\end{array}$ & $\begin{array}{c}\text { Tinggi } \\
\text { tongkol utama } \\
(\mathrm{cm})\end{array}$ & $\begin{array}{c}\text { Diameter } \\
\text { batang }(\mathrm{cm})\end{array}$ \\
\hline SD3 & 253.0 & 147.6 & 19.3 \\
Super Sweet & $274.4^{*}$ & $171.0^{*}$ & 20.9 \\
Bonanza & 258.9 & 136.4 & 22.8 \\
Sweet Boy & $225.5^{*}$ & $93.9^{*}$ & 19.5 \\
SG 75 & $222.2^{*}$ & $124.2^{*}$ & 19.3 \\
\hline
\end{tabular}

"Berbeda nyata dengan verietas SD3 dengan uji Dunnet pada taraf $5 \%$.

Panjang daun, panjang tongkol dan diameter tongkol genotipe SD3 berbeda nyata dengan varietas pembanding, sedangkan lebar daun tidak berbeda nyata. Daun genotipe SD3 memiliki lebar daun $10.4 \mathrm{~cm}$, sedangkan varietas pembanding memiliki lebar daun 9.6-15.3 cm. Panjang daun SD3 $(89.7 \mathrm{~cm})$ berbeda nyata dengan Sweet Boy $(99.4 \mathrm{~cm})$, sedangkan dibandingkan dengan varietas Super Sweet (96.5 $\mathrm{cm})$, Bonanza $(95.8 \mathrm{~cm})$ dan SG $75(83.3 \mathrm{~cm})$ tidak berbeda nyata. Daun genotipe SD3 lebih pendek dibandingkan dengan daun varietas Sweet Boy. Selain dipengaruhi oleh faktor genetik, perbedaan panjang daun dapat disebabkan oleh perbedaan jarak tanam dan ketersediaan hara bagi tanaman (Zainudin 2005). 
Panjang tongkol genotipe SD3 $(18.86 \mathrm{~cm})$ berbeda nyata dengan Sweet Boy $(17.04 \mathrm{~cm})$, sedangkan dibandingkan dengan varietas Super Sweet $(19.60 \mathrm{~cm})$, Bonanza $(20.17 \mathrm{~cm})$ dan SG 75 $(17.68 \mathrm{~cm})$ tidak berbeda nyata. Tongkol genotipe SD3 lebih panjang dibandingkan dengan tongkol varietas Sweet Boy. Diameter tongkol SD3 (45.56 $\mathrm{cm})$ berbeda nyata dengan Super Sweet $(50.62$ $\mathrm{cm})$, Bonanza $(53.94 \mathrm{~cm})$ dan Sweet Boy (51.21 $\mathrm{cm})$ tetapi tidak berbeda nyata dengan SG 75 $(47.22 \mathrm{~cm})$. Diameter tongkol SD3 lebih kecil dibandingkan dengan Super Sweet, Bonanza, dan Sweet Boy. Peubah panjang dan diameter tongkol lebih dipengaruhi oleh faktor genetik dibandingkan faktor lingkungan (Admaja 2006) dan (Muhsanati 2008). Made (2010) melaporkan bahwa panjang dan diameter dapat dipengaruhi oleh pemupukan dan jumlah tanaman per lubang.

Tabel 4. Nilai tengah panjang daun, lebar daun, panjang tongkol, dan diameter tongkol genotipe SD3 dengan empat varietas komersial sebagai pembanding

\begin{tabular}{lcccc}
\hline Varietas & $\begin{array}{c}\text { Panjang } \\
\text { daun }(\mathrm{cm})\end{array}$ & $\begin{array}{c}\text { Lebar } \\
\text { daun } \\
(\mathrm{cm})\end{array}$ & $\begin{array}{c}\text { Panjang } \\
\text { tongkol } \\
(\mathrm{cm})\end{array}$ & $\begin{array}{c}\text { Diameter } \\
\text { tongkol } \\
(\mathrm{cm})\end{array}$ \\
\hline SD3 & 89.7 & 10.4 & 18.8 & 47.5 \\
Super Sweet & 96.5 & 9.6 & 19.5 & $50.6^{*}$ \\
Bonanza & 95.8 & 11.9 & 20.1 & $53.9^{*}$ \\
Sweet Boy & $99.3^{*}$ & 13.1 & $17.0^{*}$ & $51.2^{*}$ \\
SG 75 & 83.3 & 15.31 & 17.6 & 47.2 \\
\hline
\end{tabular}

Berbeda nyata dengan verietas SD3 dengan uji Dunnet pada taraf $5 \%$.

Karakter lain yang diamati adalah bobot tongkol dengan kelobot dan bobot tongkol tanpa kelobot. Bobot tongkol berkelobot SD3 (337.3 g) berbeda nyata dengan Bonanza (401.0 g), tetapi tidak berbeda nyata dengan varietas pembanding lainnya. Bobot tongkol berkelobot SD3 lebih rendah dibandingkan varietas Bonanza. Bobot tongkol tanpa kelobot SD3 (221.4 g) berbeda nyata dengan Bonanza (294.7 g), tetapi tidak berbeda nyata dengan varietas pembanding lainnya. Bobot tongkol tanpa kelobot genotipe SD3 lebih rendah dibandingkan bobot tongkol tanpa klobot varietas Bonanza. Bobot tongkol tanpa kelobot dan bobot tongkol dengan kelobot lebih dipengaruhi oleh faktor lingkungan dibandingkan faktor genetik dan mempunyai heretabilitas yang rendah (Admaja 2006). Peubah bobot tongkol dengan kelobot dan bobot tongol tanpa kelobot dapat dipengaruhi oleh jumlah butir benih per lubang dan dosis pemupukan Urea (Made 2010).
Tabel 5. Nilai tengah bobot tongkol dengan kelobot dan bobot tongkol tanpa kelobot genotipe SD3 dengan empat varietas komersial sebagai pembanding

\begin{tabular}{lrc}
\hline \multicolumn{1}{c}{ Varietas } & $\begin{array}{r}\text { Bobot tongkol } \\
\text { berkelobot }(\mathrm{g})\end{array}$ & $\begin{array}{c}\text { Bobot tongkol } \\
\text { tanpa kelobot }(\mathrm{g})\end{array}$ \\
\hline SD3 & 337.3 & 221.4 \\
Super Sweet & 353.9 & 264.3 \\
Bonanza & $401.0^{*}$ & $294.7^{*}$ \\
Sweet Boy & 305.7 & 242.1 \\
SG 75 & 315.4 & 234.2 \\
\hline
\end{tabular}

*Berbeda nyata dengan verietas SD3 dengan uji Dunnet pada taraf $5 \%$.

Peubah jumlah baris biji dan jumlah biji dalam baris dipengaruhi oleh varietas jagung manis. Jumlah baris biji pada tongkol SD3 (15.1 biji) berbeda nyata dengan varietas Super Sweet (13.6 biji), tetapi tidak berbeda nyata dengan varietas pembanding lainya. Jumlah baris biji pada tongkol SD3 lebih banyak dibandingkan varietas Super Sweet. Jumlah biji dalam baris genotipe SD3 adalah 35.2 butir sedangkan varietas pembanding mempunyai kisaran jumlah biji dalam baris 32.4 sampai 38.6 butir. Made (2010) melaporkan bahwa jumlah biji per tongkol dipengaruhi oleh dosis pupuk Urea dan jumlah butir per lubang. Diduga, jumlah baris biji pada tongkol dan jumlah biji dalam baris SD3 dapat ditingkatkan dengan penambahan dosis Urea atau penanaman satu baris per lubang.

Tabel 6. Nilai tengah jumlah baris biji dan jumlah biji dalam baris genotipe SD3 dengan empat varietas komersial sebagai pembanding

\begin{tabular}{lcc}
\hline Varietas & $\begin{array}{c}\text { Jumlah baris biji Jumlah biji dalam } \\
\text { pada tongkol }\end{array}$ & baris \\
\hline SD3 & 15,1 & 35.2 \\
Super Sweet & $13.6^{*}$ & 38.6 \\
Bonanza & 15.7 & 38.1 \\
Sweet Boy & 15.1 & 32.4 \\
SG 75 & 14.5 & 36.7 \\
\hline
\end{tabular}

*Berbeda nyata dengan verietas SD3 dengan uji Dunnet pada taraf $5 \%$.

Penyakit bulai berkembang pada suhu 27 ${ }^{\circ} \mathrm{C}$. Suhu rata-rata di tempat penelitian tidak mencapai $27{ }^{\circ} \mathrm{C}$ sehingga tidak ada tanaman jagung yang terkena penyakit bulai. Sufiani (2002) melaporkan bahwa intesitas serangan bulai meninggi saat akhir musim hujan karena suhu dan kelembaban lingkungan tinggi. Admaja (2006) melaporkan bahwa penularan penyakit bulai pada lokasi penelitian Cihideung lebih tinggi dibandingkan pada lokasi Tajur. Hal ini disebabkan pada lokasi Cihideung terdapat lahan 
petani yang melakukan penanaman jagung manis lebih awal daripada penanaman jagung manis penelitian. Bobot 1000 butir benih jagung manis genotipe SD3 tidak berbeda nyata dengan empat varietas komersial yang digunakan sebagai pembanding. Genotipe SD mempunyai bobot 1000 butir $140.5 \mathrm{~g}$, sedangkan empat varietas pembanding mempunyai kisaran bobot 1000 butir benih 138.8 sampai 142.8 g. Bobot 1000 butir benih masing-masing varietas sebagai berikut, Super Sweet (138.8 g), Bonanza (142.8 g), Sweet Boy (138.8 g), dan SG 75 (138.8 g).

Tabel 7. Nilai tengah tanaman yang terserang penyakit bulai, tanaman yang dipanen, bobot 1000 butir benih genotipe SD3 dengan empat varietas komersial sebagai pembanding

\begin{tabular}{lccc}
\hline Varietas & $\begin{array}{c}\text { Tanaman } \\
\text { yang } \\
\text { terserang } \\
\text { bulai (\%) }\end{array}$ & $\begin{array}{c}\text { Tanaman } \\
\text { yang } \\
\text { dipanen }(\%)\end{array}$ & $\begin{array}{c}\text { Bobot 1000 } \\
\text { butir benih } \\
(\%)\end{array}$ \\
\hline SD3 & 0 & 64.7 & 140.5 \\
Super Sweet & 0 & 53.5 & 138.8 \\
Bonanza & 0 & 42.9 & 142.8 \\
Sweet Boy & 0 & 71.0 & 138.8 \\
SG 75 & 0 & 45.1 & 138.8 \\
\hline
\end{tabular}

Bobot tajuk atas dan indeks panen tongkol tanpa kelobot SD3 tidak berbeda nyata dengan bobot tajuk atas semua varietas pembanding. Bobot tajuk atas varietas SD3 467.7 g, sedangkan bobot tajuk atas varietas pembanding berkisar 396.5 sampai $526.8 \mathrm{~g}$. Indeks panen tongkol tanpa kelobot SD3 0.32, sedangkan varietas pembanding berkisar 0.34 sampai 0.38. Produktivitas SD3 (18.64 ton) berbeda nyata dengan produktivitas Bonanza (24.82 ton), tetapi tidak berbeda nyata dengan varietas pembanding lainnya. Produktivitas SD3 lebih rendah dibandingkan produktivitas Bonanza.

Tabel 8. Nilai tengah bobot tajuk atas, indeks panen tongkol tanpa kelobot, dan produktivitas genotipe SD3 dengan empat varietas komersial sebagai pembanding

\begin{tabular}{lccc}
\hline Varietas & $\begin{array}{c}\text { Bobot } \\
\text { tajuk atas } \\
(\mathrm{g})\end{array}$ & $\begin{array}{c}\text { Indeks panen } \\
\text { tongkol } \\
\text { tanpa } \\
\text { kelobot }\end{array}$ & $\begin{array}{c}\text { Produktivitas } \\
\left.\text { ton ha }^{-1}\right)\end{array}$ \\
\hline SD3 & 467.7 & 0.32 & 18.64 \\
Super Sweet & 526.8 & 0.33 & 22.26 \\
Bonanza & 512.1 & 0.35 & $24.82^{*}$ \\
Sweet Boy & 396.5 & 0.38 & 20.39 \\
SG 75 & 426.5 & 0.35 & 19.72 \\
* Berbeda nyata dengan verietas SD3 dengan uji Dunnet pada \\
taraf 5\%.
\end{tabular}

Kadar PTT diukur empat hari setelah panen. Selama empat hari, jagung manis disimpan dalam kertas amplop warna coklat. Kadar PTT genotipe SD3 $\left(19.2^{\circ}\right.$ brix $)$ berbeda nyata dengan Super Sweet $\left(16.6^{\circ}\right.$ brix), tetapi tidak berbeda nyata dengan varietas pembanding lainnya. Kadar PTT genotipe SD3 lebih tinggi dibandingkan dengan varietas Super Sweet. Pengukuran kadar PTT empat hari setelah panen menyebabkan kandungan PTT dalam jagung manis berubah. Muhsanati et al. (2008) melaporkan bahwa kadar PTT menurun setelah disimpan selama 2 minggu, sehingga jauh dibawah kisaran $13 \%$ sampai $14 \%$. Sufiani (2002) melaporkan bahwa kadar PTT jagung manis tidak selalu sejalan dengan kadar kemanisan. Hal ini karena PTT juga menghitung pati dan bentuk gula yang tidak manis.

Tabel 9. Nilai tengah kadar padatan terlarut total (PTT) genotipe SD3 dengan empat varietas komersial sebagai pembanding

\begin{tabular}{lc}
\hline Varietas & Kadar PTT ( ${ }^{\circ}$ brix $)$ \\
\hline SD3 & 19.2 \\
Super Sweet & $16.6^{*}$ \\
Bonanza & 18.6 \\
Sweet Boy & 17.8 \\
SG 75 & 18.1 \\
\hline
\end{tabular}

Berbeda nyata dengan verietas SD3 dengan uji Dunnet pada taraf $5 \%$.

\section{Peubah Pertumbuhan Kualitatif}

Berdasarkan pengamatan visual bentuk batang genotipe SD3 menunjukkan bentuk pipih, tidak berbeda dengan varietas pembanding lainnya. Untuk pengamatan warna daun digunakan standar bagan warna daun (BWD). Berdasarkan pengamatan tampak bahwa peubah warna daun genotipe SD3 dengan varietas pembanding tidak menunjukkan perbedaan. Warna daun SD3 dan varietas pembanding adalah hijau tua.

Tabel 10. Bentuk batang dan warna daun genotipe SD3 dengan empat varietas komersial sebagai pembanding

\begin{tabular}{lcc}
\hline Varietas & Bentuk batang & Warna daun \\
\hline SD3 & pipih & hijau tua \\
Super Sweet & pipih & hijau tua \\
Bonanza & pipih & hijau tua \\
Sweet Boy & pipih & hijau tua \\
SG 75 & pipih & hijau tua \\
\hline
\end{tabular}

Bentuk tongkol merupakan salah satu kriteria kualitas jagung manis. Berdasarkan hasil uji preferensi terhadap bentuk tongkol, bentuk tongkol kerucut lebih disukai $(80 \%)$ daripada 
cerutu (silindris) (Sufiani 2002). Peubah bentuk tongkol diamati dengan membandingkan lingkar tongkol bagian pangkal, tengah, dan ujung tongkol dengan lingkar bagian tengah. Hasil pengamatan visual menunjukkan bahwa genotipe SD3 memiliki kecenderungan bentuk tongkol silindris, tidak berbeda dengan varietas pembanding. Warna biji genotipe SD3 dan varietas SG 75 memiliki warna biji yang oranye, sedangkan tiga verietas pembanding lainnya memiliki warna kuning muda.

Tabel 11. Bentuk tongkol dan warna biji genotipe SD3 dengan empat varietas komersial sebagai pembanding

\begin{tabular}{lcc}
\hline Varietas & Bentuk tongkol & Warna biji \\
\hline SD3 & silindris & oranye \\
Super Sweet & silindris & kuning muda \\
Bonanza & silindris & kuning muda \\
Sweet Boy & silindris & kuning muda \\
SG 75 & silindris & oranye \\
\hline
\end{tabular}

\section{KESIMPULAN}

Genotipe SD3 belum mampu bersaing dengan varietas bersari bebas pembanding. Genotipe SD3 lebih unggul dibandingkan dengan Super Sweet (varietas bersari bebas) pada jumlah baris biji dan kadar padatan terlarut total, sedangkan jika dibandingkan dengan Bonanza dan Sweet Boy (varietas hirbida), genotipe SD3 masih belum bisa bersaing.

\section{DAFTAR PUSTAKA}

Admaja G. 2006. Evaluasi adaptabilitas tiga genotipe (Zea mays saccharata Sturt.) di dua lokasi dataran rendah [skripsi]. Bogor (ID): Institut Pertanian Bogor.

[Deptan] Departemen Pertanian (ID). 2012. Volume ekspor impor benih sayuran [Internet]. [diunduh 2013 Maret 06]. Tersedia pada: http://hortikultura.deptan.go.id/?q=node/ $\underline{438}$

[Deptan] Departemen Pertanian (ID). 2012. Nilai ekspor impor benih sayuran [Internet]. [diunduh 2013 Maret 06] . Tersedia pada:http://hortikultura.deptan.go.id/?q= $\underline{\text { node } / 440}$
Kumalasari NR, Abdullah, Jayadi S. 2005. Pengaruh pemberian mulsa Chromolaena odorata (L.) Kings and Robins pada kandungan mineral $\mathrm{P}$ dan $\mathrm{N}$ tanah latosol dan produktivitas hijauan jagung (Zea mays L.). Media Peternakan [Internet]. [diunduh 2013 Maret 23]; 28(1):29-36. Tersedia pada: http://202.124.205.111/index.php/media peternakan/article/view/800/216

Made U. 2010. Respons berbagai populasi tanaman jagung manis (Zea mays saccharata Sturt.) terhadap pemberian pupuk Urea. $J$ Agroland [Internet]. [diunduh 2013 Maret 23]; 17(2):138-143. Tersedia pada: http://jurnal.untad.ac.id/jurnal/index.php/ AGROLAND/article/view/294

Muhsanati, Syarif A, Rahayu S. 2008. Pengaruh beberapa takaran kompos tithonia terhadap pertumbuhan dan hasil jagung manis (Zea mays saccharata) [Internet]. [diunduh 2013 Maret 23]. Jerami. 1(2):87-91. Tersedia pada: http://repository.unand.ac.id/id/eprint/253 $\underline{2}$

[Pemkab Bandung] Pemerintah Kabupaten Bandung (ID). 2011. Peta dan topografi [Internet]. [diunduh 2013 Maret 14]. Tersedia pada: http://www.bandungkab.go.id/arsip/19/pet a-dan-topografi

Rubatzky VE, Yamaguchi M. 1995. Sayuran Dunia : Prinsip, Produksi, dan Gizi. Jilid ke-1. Herison C, penerjemah. Bandung (ID): ITB Pr. Terjemahan dari: World Vegetables: Principles, Production, and Nutritive Values.

Santoso MB. 2004. Efesiensi energi dan produktivitas pada tumpangsari jagung manis (Zea mays saccharata Sturt.) dan berbagai kerapatan kacang hijau (Vigna radiata L.) dengan pengolahan tanah yang berbeda [tesis]. Bogor (ID): Institut Pertanian Bogor.

Setyani S, Medikasari, Astuti WI. 2009. Fortifikasi jagung manis dan kacang hijau terhadap sifat fisik, kimia, dan organoleptik susu jagung manis kacang hijau [Internet]. [diunduh 2013 Maret 23]. Jurnal Teknologi Industri dan Hasil Pertanian. 14(2):107-119. Tersedia 
pada:

http://jurnal.fp.unila.ac.id/index.php/JTH $\underline{\text { P/article/view/59/67 }}$

Sufiani R. 2002. Evaluasi karakteristik empat genotipe jagung manis (Zea mays saccharata Sturt.) di kebun percobaan IPB Tajur Bogor [skripsi]. Bogor (ID): Institut Pertanian Bogor.
Zainudin A. 2005. Respons tiga varietas jagung manis (Zea mays saccharata Sturt) terhadap perlakuan pupuk organik. GAMMA [Internet]. [diunduh 2013 Maret 23]; 1(1):69-75. Tersedia pada: http://ejournal.umm.ac.id/index.php/gam $\mathrm{ma} /$ article/viewFile/721/744 umm_scientific_journal.pdf 